\title{
Pengolahan Limbah Industri Pengolahan Ikan Dengan Teknologi Gabungan Upflow Anaerobic Sludge Blanket (UASB)-Wetland
}

\author{
Upflow Anaerobic Sludge Blanket (UASB)-Wetland Integrated \\ Technology for Fish-Processing Wastewater Treatment Plant
}

RUSTIANA YULIASNI, BEKTI MARLENA, SYARIFA ARUM KUSUMASTUTI, CHOLID SYAHRONI

\author{
Balai Besar Teknologi Pencegahan Pencemaran Industri \\ Jl. Ki Mangunsarkoro No. 6 Semarang \\ Email:rustianay@yahoo.com
}

\begin{abstract}
Upflow Anaerobic Sludge Blanket (UASB)-Wetland Integrated Technology was applied to treating fishprocessing wastewater, taking into account for its simplicity, rapid and economical as well as its capability for reducing pollutant, so the effluent can fulfill effluent standard regulation. The research was carried out by the following steps: identification of wastewater characteristics, WWTP design and construction, and WWTP operational trials. The trials showed that UASB could remove COD average $72.3 \%$ and could achieve the highest COD removal of $95.42 \%$, with retention time 24 hours. Wetland could remove COD $52.9 \%$ on average and the highest COD removal was $78.22 \%$. Simultaneously UASB-Wetland hybrid Technology could remove $86.25 \%$ COD on average, and the highest COD removal was $98.58 \%$. Effluent has compiled the stream standard regulation and can be reused for fish farming.
\end{abstract}

Keywords: fish processing wastewater, high organic wastewater treatment, integrated UASB-Wetland, Anaerobic-Aerobic WWTP

\begin{abstract}
ABSTRAK
Teknologi gabungan Upflow Anaerobic Sludge Blanket (UASB) - wetland diaplikasikan untuk mengolah air limbah industri pengolahan ikan dengan pertimbangan bahwa teknologi ini murah dan mudah pengoperasiannya serta dapat mereduksi polutan sehingga kualitas effluent memenuhi syarat baku mutu. Instalasi pengolahan limbah terdiri dari unit ekualisasi, UASB dan wetland. Hasil uji coba pengolahan dengan UASB menujukkan bahwa penurunan COD rata-rata $72,3 \%$ dengan persen penurunan tertinggi mencapai $95,42 \%$ dan penurunan COD dengan proses wetland rata-rata $52,9 \%$ dengan penurunan tertinggi mencapai $78,22 \%$. Secara keseluruhan proses IPAL hibrid UASB-Wetland mampu menurunkan nilai COD rata-rata sebesar $86,25 \%$ dengan penurunan tertinggi mencapai $98,58 \%$. Limbah terolah (effluent) sudah memenuhi baku mutu yang disyaratkan serta dapat dimanfaatkan kembali (reuse) sebagai sumber air untuk budidaya perikanan darat.
\end{abstract}

Kata kunci: air limbah pengolahan ikan, pengolahan limbah organik tinggi, gabungan UASB-wetland, IPAL anaerobik-aerobik

\section{PENDAHULUAN}

\subsection{Latar Belakang}

Industri pengolahan ikan merupakan salah satu industri yang banyak menggunakan air untuk proses produksinya, sehingga kuantitas limbah yang dihasilkan besar ${ }^{(1)}$. Disamping itu kadar polutan organik berupa $\mathrm{C}, \mathrm{N}$ dan $\mathrm{P}$ juga relatif sangat tinggi, sehingga jika ingin melakukan pengolahan limbah sampai memenuhi baku mutu, diperlukan biaya investasi maupun operasional yang cukup besar pula(2). Untuk mengatasi permasalahan air limbah tersebut, maka teknologi hibrida Upflow Anaerobic Sludge Blanket (UASB) wetland diaplikasikan, dengan pertimbangan bahwa teknologi ini murah dan mudah pengoperasiannya serta dapat mereduksi polutan sehingga kualitas effluent memenuhi syarat untuk dapat digunakan kembali sebagai sumber air budidaya ikan.

UASB digunakan untuk mengolah air limbah yang mempunyai kandungan organik karbon yang tinggi. Inti dari kesuksesan desain pengolahan UASB adalah kemampuannya dalam menahan lumpur biologi berkonsentrasi tinggi dan keefektifan dari pemisahan fase padat, cair dan gas di dalam reaktor. Lumpur biologi berkonsentrasi tinggi ini kerap disebut dengan granul, dan terbentuknya granul di dalam reaktor UASB tergantung pada kecepatan aliran air vertikal (Upflow velocity) 
dan waktu tinggal (hydraulic retention time/HRT) ${ }^{(3)}$. Sedangkan proses pemisahan fase padat (lumpur), cair (air limbah) dan gas (biogas) dicapai dengan mendesain gas-liquidsludge separator seperti yang sudah dilakukan ${ }^{(4)}$.

Sejumlah peneliti dari BBTPPI Semarang telah berhasil menerapkan teknologi UASB untuk mengolah air limbah dengan kadar organik karbon tinggi di sejumlah industri. Moertinah dan Sartamtomo,2012(5) telah berhasil membuat reaktor UASB untuk mengolah air limbah industri kertas kraft dengan efisiensi penurunan COD mencapai $87 \%$ pada debit air limbah $2 \mathrm{~m}^{3} /$ hari dan konsentrasi COD masuk $2.500 \mathrm{mg} / \mathrm{L}$. Moenir dkk, 2014(6) juga telah menerapkan teknologi UASB untuk mengolah air limbah industri minuman ringan dengan efisiensi penurunan COD mencapai $88,51 \%$ pada debit air limbah 2,297 $\mathrm{m}^{3} /$ hari dan konsentrasi COD masuk $3.000-5.000 \mathrm{mg} / \mathrm{L}$.

Unit Wetland digunakan untuk mereduksi kadar nitrogen organik didalam air limbah. Lahan basah buatan (constructed wetland) adalah sistem yang dirancang dan dibangun dengan memanfaatkan proses alami yang melibatkan vegetasi lahan basah, tanah, dan mikroba untuk membantu pengolahan air limbah ${ }^{(7)}$. Kemampuan penurunan Nitrogen industri pengolahan lele di unit wetland telah dibahas tersendiri secara spesifik di mana kemampuan penurunan ammonia di wetland mencapai $87,34 \%{ }^{(8)}$, Kemampuan wetland dalam menurunkan ammonia, nitrat dan nitrit di beberapa industry juga telah dibahas dalam paper yang ditulis oleh Lamchaturapatr dan Vymazal $^{(9 ; 10)}$.

Penelitian ini akan menitik beratkan kepada kemampuan dari teknologi UASBwetland dalam mengolah air limbah industri pengolahan lele sehingga dapat mencapai kualitas effluent yang memenuhi syarat untuk digunakan kembali.

\subsection{Tujuan Penelitian}

Tujuan dari Penelitian ini adalah aplikasi teknologi hibrid UASB - Wetland untuk mengolah air limbah industri pengolahan ikan dan potensi pemanfaatan air limbah terolah sebagai air untuk budidaya perikanan (aquaculture).

\section{BAHAN DAN METODE}

\subsection{Alat}

Bangunan IPAL yang terdiri dari satu unit ekualisasi, satu unit pre-treatment, satu unit UASB dan satu unit wetland, dua pompa air dengan timer, satu pompa submersible dengan water level. Gambar lay out unit IPAL bisa dilihat dalam gambar 1. Sedangkan gambar detail unit IPAL bisa dilihat di gambar 2 .

Unit ekualisasi adalah bangunan berbentuk persegi, dengan $P=2 \mathrm{~m} ; \mathrm{L}=4 \mathrm{~m}$. kedalaman: $1 \mathrm{~m}$, Unit UASB terdiri dari bangunan berbentuk empat persegi panjang dengan panjang $1,90 \mathrm{~m}$, lebar $1,20 \mathrm{~m}$, serta ketinggian 3,10 m. Reaktor UASB dilengkapi dengan pipa drain dibagian bawah untuk mengeluarkan lumpur, GLSS (Gas Liquid Sludge Separator), pipa saluran gas outlet, pipa saluran outlet air limbah dan kaca pantau pada dinding untuk melihat proses anaerob.

Unit Wetland berbentuk persegi empat dengan panjang $6 \mathrm{~m}$, lebar $3 \mathrm{~m}$ dan kedalaman $1 \mathrm{~m}$, terbagi dalam 3 kompartemen. Tiap kompartemen diisi dengan lapisan batu kerikil dengan kedalaman total $0,75 \mathrm{~m}$. Bagian teratas lapisan batu kerikil diisi batu kerikil berukuran kecil ( $D=0.5-1 \mathrm{~cm})$ dengan kedalaman 0,25 m, kemudian bagian tengah diisi dengan batu kerikil berukuran sedang ( $D$ $=1-3 \mathrm{~cm}$ ) kedalaman $0,25 \mathrm{~m}$, dan bagian terbawah diisi dengan batu kerikil berukuran besar $D=3-7 \mathrm{~cm}$ ) dengan kedalaman 0,25 m. Dalam penelitian ini digunakan desain teknis IPAL yang telah digunakan oleh peneliti sebelumnya ${ }^{(11)}$.

\subsection{Bahan}

Bahan baku dalam penelitian ini adalah air limbah industri pengolahan ikan dengan kualitas air limbah sebagai berikut: COD 533 3163 mg/L, BOD 189,2 - 1727 mg/L, Ammonia 19,4 - 55,4 mg/L, alkalinitas 236,9 - 873 $\mathrm{mg} / \mathrm{L}$, total $\mathrm{N}=62,3-140,8 \mathrm{mg} / \mathrm{L}$, total $\mathrm{P}=$ $6,267-10,22 \mathrm{mg} / \mathrm{L}, \mathrm{pH}=6,2-7,1$.

Bibit mikroba anaerob yang dipakai di unit UASB adalah bibit mikroorganisme yang sudah teraklimatisasi. Mikroba ditambah dengan makro nutrient yang terdiri dari $\mathrm{N}, \mathrm{P}$, dan $\mathrm{K}$ dan juga mikro nutrien yang berupa vitamin dan mineral untuk mikroba anaerob, dengan komposisi seperti yang dipakai oleh Fedorak et all $^{(12)}$.

Tanaman yang dipakai untuk wetland adalah Cana (Canna fraccida), Papirus (Cyperus papyrus L.) dan Heliconia (Heliconia psittacorum).

\subsection{Metode}

Penelitian ini dilakukan di salah satu industri kecil pengolahan lele di kabupaten Boyolali, Jawa tengah. Metode penelitian dibagi menjadi 2 tahap. Tahap pertama adalah tahap inokullasi- aklimatisasi bakteri di unit UASB, dan tahap kedua adalah tahap running full scale IPAL. Tahap inokulasi dilakukan di unit UASB, dimana sebanyak $2 \mathrm{~m}^{3}$ bibit bakteri 
dimasukan ke dalam reaktor. Sebanyak 0,1\% V/V larutan mikro dan makronutrient ditambahkan ke dalam reaktor UASB, kemudian tahap aklimatisasi adalah tahap dimana limbah diumpankan kedalam reaktor UASB dengan kualitas COD yang dinaikkan sedikit demi sedikit.
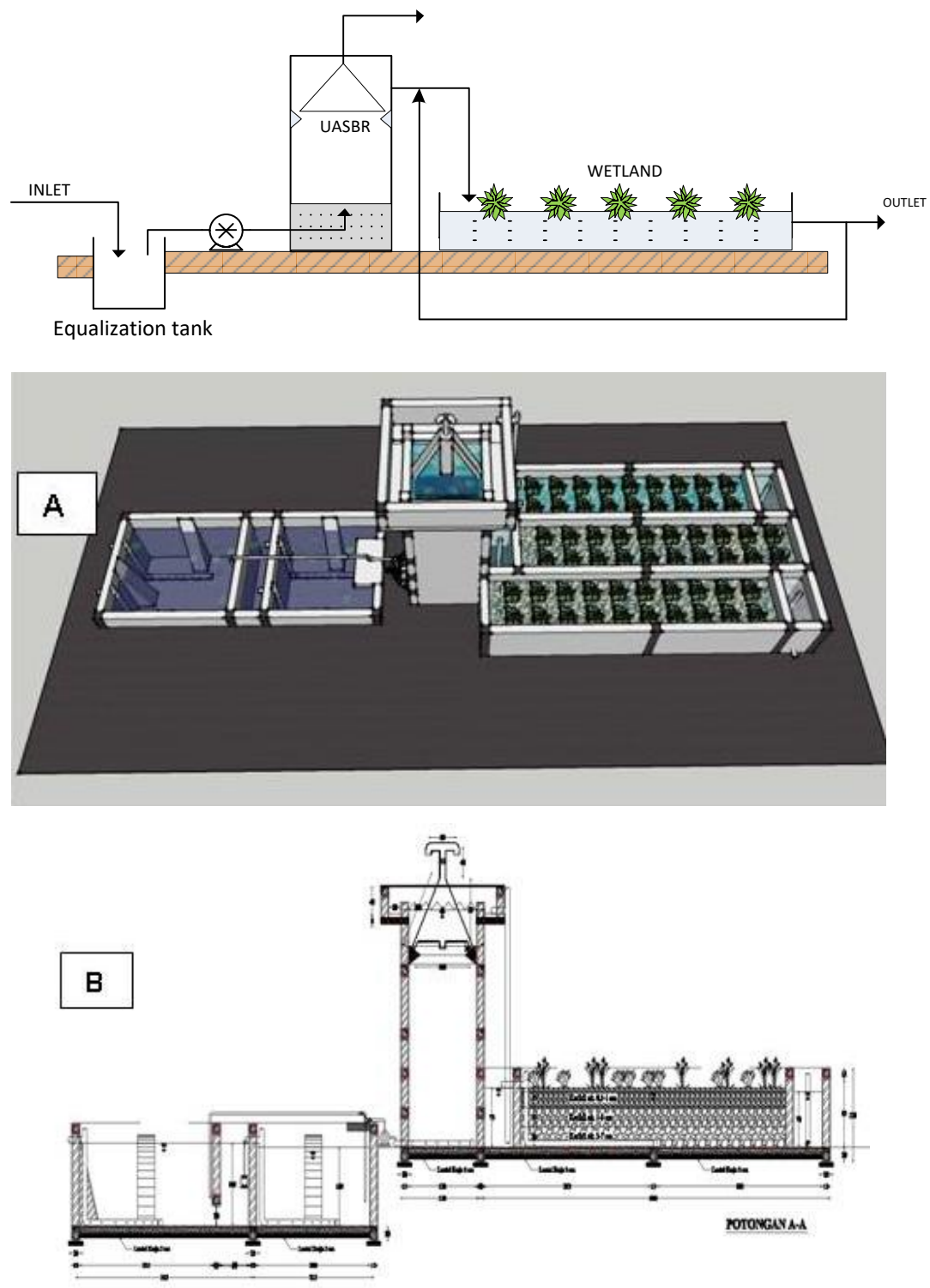

Gambar 1. Layout IPAL

Setelah reaktor UASB siap, tahap full scale dilakukan dengan cara mengalirkan air limbah secara overflow ke dalam bak ekualisasi, kemudian dengan menggunakan pompa otomatis yang sudah diatur dengan menggunakan water level, air limbah akan dipompa ke dalam reaktor UASB. Keluaran dari unit UASB kemudian akan mengalir secara gravitasi ke unit wetland. Effluent dari unit wetland akan mengalir ke bak kontrol yang kemudian dialirkan ke kolam ikan (Gambar 1).

Metode pengambilan sampel dilakukan secara grab, dengan mengambil sampel di inlet unit ekualisasi, outlet ekualisasi yang juga adalah inlet UASB, outlet UASB yang juga merupakan inlet wetland, dan terakhir di bak kontrol (keluaran dari unit wetland).

Parameter yang diuji adalah Chemical Oxygen Demand (COD), dan parameter yang sesuai dengan BMAL Perda Jateng No. Tahun 2012 Baku Mutu Air Limbah Golongan I dan Kriteria Mutu Air untuk kegiatan Budidaya Perikanan PP. No. 82 tahun 2001. Metode analisa mengacu kepada metode analisa APHA AWWA 2005. 


\section{HASIL DAN PEMBAHASAN}

Kemampuan teknologi kombinasi UASBwetland dalam mengolah limbah industri pengolahan lele sehingga bukan hanya memenuhi baku mutu tetapi juga memenuhi syarat untuk digunakan kembali sebagai air baku untuk kegiatan budidaya ikan akan dibahas dalam paper ini. Kemampuan tiap unit pengolahan yaitu UASB dan wetland akan secara spesifik dievaluasi berdasarkan kemampuan unit tersebut dalam menurunkan parameter COD. COD digunakan sebagai parameter acuan dalam evaluasi kinerja unit IPAL dikarenakan uji COD yang cepat, akurat dan bisa mewakili konsentrasi polutan organik yang terdapat di air limbah. Air limbah dialirkan secara kontinyu dari bak ekualisasi, kemudian dipompa secara upflow ke unit UASB, dan keluaran dari UASB akan overflow ke unit wetland. Hasil olahan dari unit wetland selanjutnya akan masuk ke bak kontrol. Sebanyak $50 \%$ effluent akan dialirkan kembali ke unit wetland dan sebagian lagi akan menuju ke kolam ikan.

\subsection{Uji coba kinerja unit UASB.}

\subsubsection{Kinerja UASB pada tahap Inokulasi- aklimatisasi}

Kinerja UASB dimulai dengan tahap inokulasi dimana mikrooranisme dimasukan ke dalam reaktor dan ada penambahan makro dan mikronutrien. Sedangkan tahap aklimatisasi dilakukan dengan mengumpankan air limbah yang di naikkan konsentrasinya sedikit demi sedikit yang kemudian di ukur pemurunan CODnya. Tahap aklimatisasi ini berlangsung kurang lebih 45 hari, dengan jumlah sampel pengamatan sebanyak 9 sampel selama kurun waktu tersebut. Hasil dari proses ini terlihat di Gambar 3.

Gambar 3. menggambarkan besarnya persen penurunan COD selama 12 kali pengamatan dalam kurun waktu 55 hari. Pada pengamatan ke 1 dan 2 (pada hari ke 0 sampai dengan hari ke 8), UASB belum mampu menurunkan COD. COD pada outlet UASB lebih besar dari pada COD inlet karena ada sedikit lumpur mikroorganisme dan nutrient yang terikut ke outlet sehingga menyebabkan nilai COD besar. Hal ini kemungkinan dikarenakan kumpulan mikroorganisme yang belum bisa membentuk flok sehingga massa mikroorganisme cenderung ringan dan karena pengaruh tekanan upflow dari pompa menyebabkan lumpur mikroorganisme tersebut terikut

Pada pengamatan ke-3 sampai dengan ke 12 (yaitu pada hari ke $10-55$ ), UASB telah mempu menurunkan kadar polutan COD dari $20 \%$ meningkat menjadi $78 \%$. Hal tersebut menunjukkan bahwa proses aklimatisasi reaktor UASB atau reaktor anaerobik pada umumnya membutuhkan waktu yang lebih lama jika dibandingkan dengan reaktor aerobik ${ }^{(13)}$. Waktu start up di reaktor UASB dalam sistem ini termasuk lebih lama dari rata-rata start up reaktor UASB yaitu maksimal 50 hari ${ }^{(14)}$.

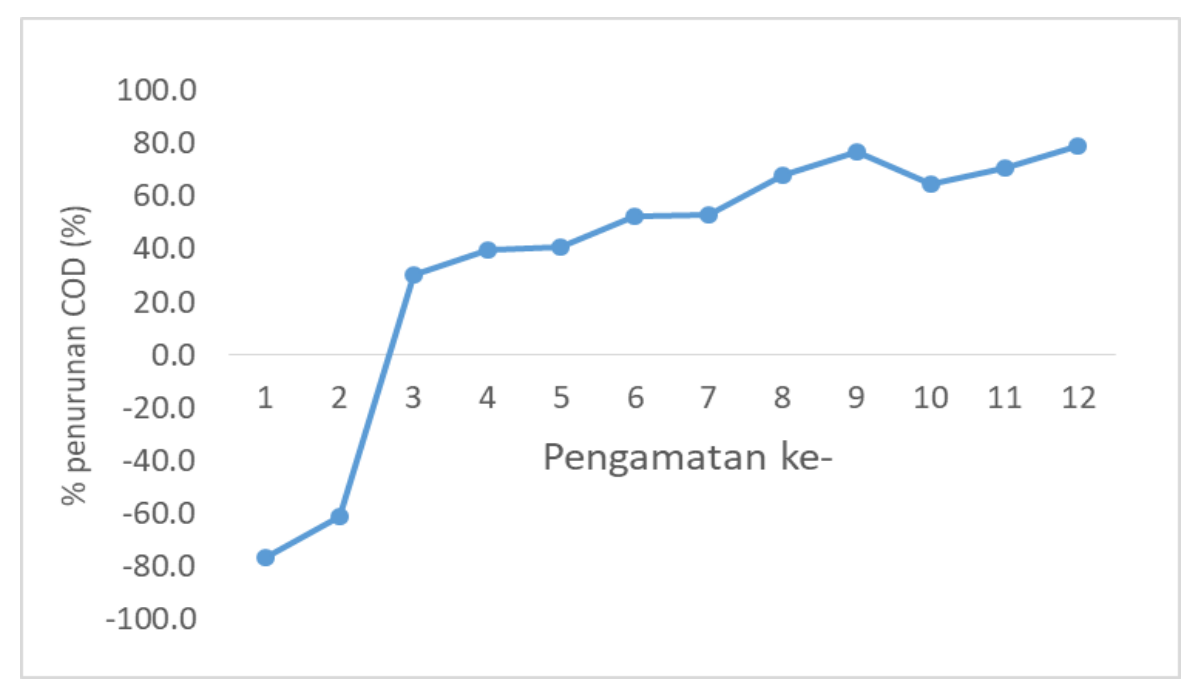

Gambar 3. Grafik Penurunan COD pada tahap inokulasi-aklimatisasi di Unit UASB

\subsubsection{Uji coba kinerja UASB pada tahap full scale}

Setelah tahap inokulasi dan aklimatisasi di unit UASB, dilakukan uji coba secara full scale.
Uji coba full scale ini dengan cara mengalirkan limbah dari bak ekualisasi kemudian dipompa secara upflow ke unit UASB, lalu overflow ke unit wetland dan kemudian terakhir di bak kontrol sebelum dialirkan ke fish pond (gambar 
1). Selama operasional IPAL secara full scale ini, sampel air limbah inlet dan outlet ditiap unit diambil dan dianalisa untuk parameter COD.

Uji coba kinerja unit UASB dilakukan dengan debit limbah masuk sebesar $1 \mathrm{~m}^{3 /}$ hari. $\mathrm{pH}$ masuk diatur antara $6-7,5$, dan konsentrasi COD influent antara 752 - $3.163 \mathrm{mg} / \mathrm{L}$. Dari hasil uji coba (Gambar 4) didapatkan bahwa penurunan COD rata-rata sebesar 72,3\% dengan penurunan tertinggi mencapai $95,42 \%$. Pada penelitian sejenis ${ }^{(15)}$ mampu menurunkan COD sebesar $92-97 \%$, namun hasil tersebut merupakan penelitian laboratorium sehingga aspek lingkungan masih dapat dikontrol dengan baik.

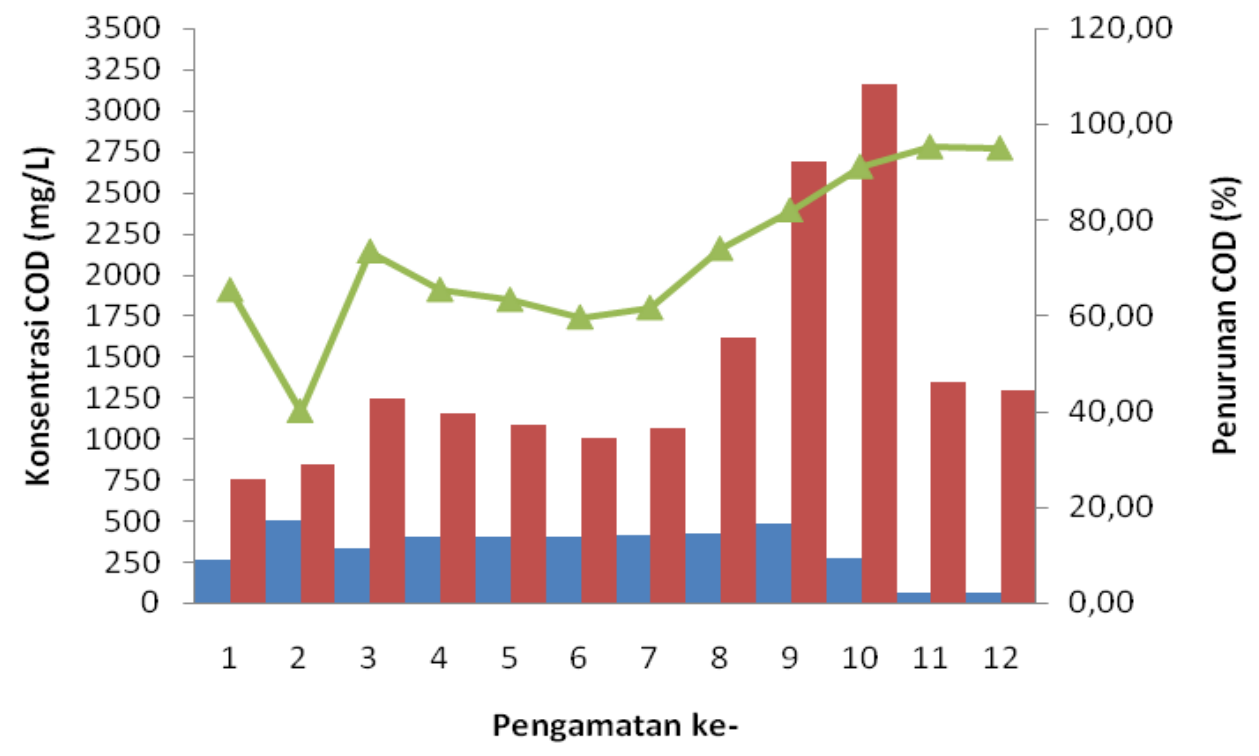

COD Outlet COD inlet $\quad-1-$ Penurunan COD

Gambar 4. Grafik Penurunan COD di Unit UASB

\subsection{Uji coba kinerja unit Wetland}

Evaluasi kinerja unit wetland dilakukan dengan cara menghitung penurunan COD inlet wetland dengan COD outlet, selama kurun waktu pengoperasian full scale. Rata-rata konsentrasi COD yang masuk ke wetland antara 61 - $479 \mathrm{mg} / \mathrm{L}$. Penurunan COD rata-rata mencapai $52,9 \%$ dengan penurunan tertinggi sebesar $78,22 \%$. Apabila dilihat IPAL secara keseluruhan (UASB-Wetland) terlihat penurunan COD dapat dilihat pada Gambar 6 dibawah ini. Penurunan COD lebih rendah daripada penurunan amonia. Jika dibandingkan data penurunan amonia yang dapat mencapai $87 \%$ (8) penurunan COD di unit wetland lebih rendah dikarenakan perpaduan kondisi aerobik dan anoksik yang ada di dalam wetland memungkinkan amonia teroksidasi menjadi nitrit dan nitrate dan kemudian tereduksi menjadi gas $\mathrm{N}_{2}$ dan menguap ke udara. Sedangkan untuk degradasi polutan organik karbon lebih banyak terjadi di unit UASB dari pada di wetland.

\subsection{Uji coba kinerja unit UASB-Wetland}

Evaluasi terhadap IPAL secara keseluruhan menunjukkan penurunan $\mathrm{COD}$ rata-rata mencapai $86,25 \%$ dengan penurunan tertinggi sebesar $98,58 \%$. Hasil yang didapat di dalam penelitian ini lebih baik jika dibandingkan dengan penelitian Moertinah dan Sartamtomo, $2012^{(5)}$ yang telah berhasil membuat reaktor UASB untuk mengolah air limbah industri kertas kraft dengan efisiensi penurunan COD mencapai $87 \%$ pada debit air limbah $2 \mathrm{~m}^{3} /$ hari dan konsentrasi COD masuk $2.500 \mathrm{mg} / \mathrm{L}$. Hasil pelitian ini juga lebih baik jika dibandingkan dengan penelitian Moenir dkk, 2014(6) yang juga telah menerapkan teknologi UASB untuk mengolah air limbah industri minuman ringan dengan efisiensi penurunan COD mencapai $88,51 \%$ pada debit air limbah 2,297 $\mathrm{m3} /$ hari dan konsentrasi COD masuk $3.000-5.000$ mg/L. Karakteristik limbah pengolahan ikan yang merupakan organik biodegradable dan tidak mengandung komponen bahan kimia yang toksik membuat efisiensi penurunan COD menjadi lebih optimal jika dibandingkan limbah kertas kraf dan limbah minuman ringan.

\subsection{Effluent Reuse untuk budidaya ikan}

Apabila dibandingkan dengan Baku Mutu Air Limbah Golongan I (Permen LH No. Tahun 2014 tentang Baku Mutu Air Limbah) kualitas 
limbah terolah dari gabungan teknologi UASB wetland sebagian besar memenuhi syarat baku mutu, kecuali parameter nitrit. Namun dari tiga kali pengamatan menunjukkan kecenderungan untuk turun, bahkan pada pengamatan yang terakhir sudah jauh di bawah baku mutu (Tabel.1).

Air limbah terolah direncanakan untuk dimanfaatkan kembali untuk budidaya perikanan yaitu ikan air tawar dan lele untuk bahan baku proses. Apabila masih ada kecenderungan parameter nitrit masih tinggi, maka dilakukan aerasi sebelum dimanfaatkan.

Untuk memenuhi persyaratan air untuk budidaya perikanan, maka dilakukan analisis air yang lebih lengkap yaitu Mutu Air Kelas tiga sesuai dengan PP No. 82 tahun 2001 tentang Pengelolaan Kualitas Air dan Pengendalian Pencemaran Air. Hasil analisis air terolah tersaji pada tabel 2 di bawah ini.

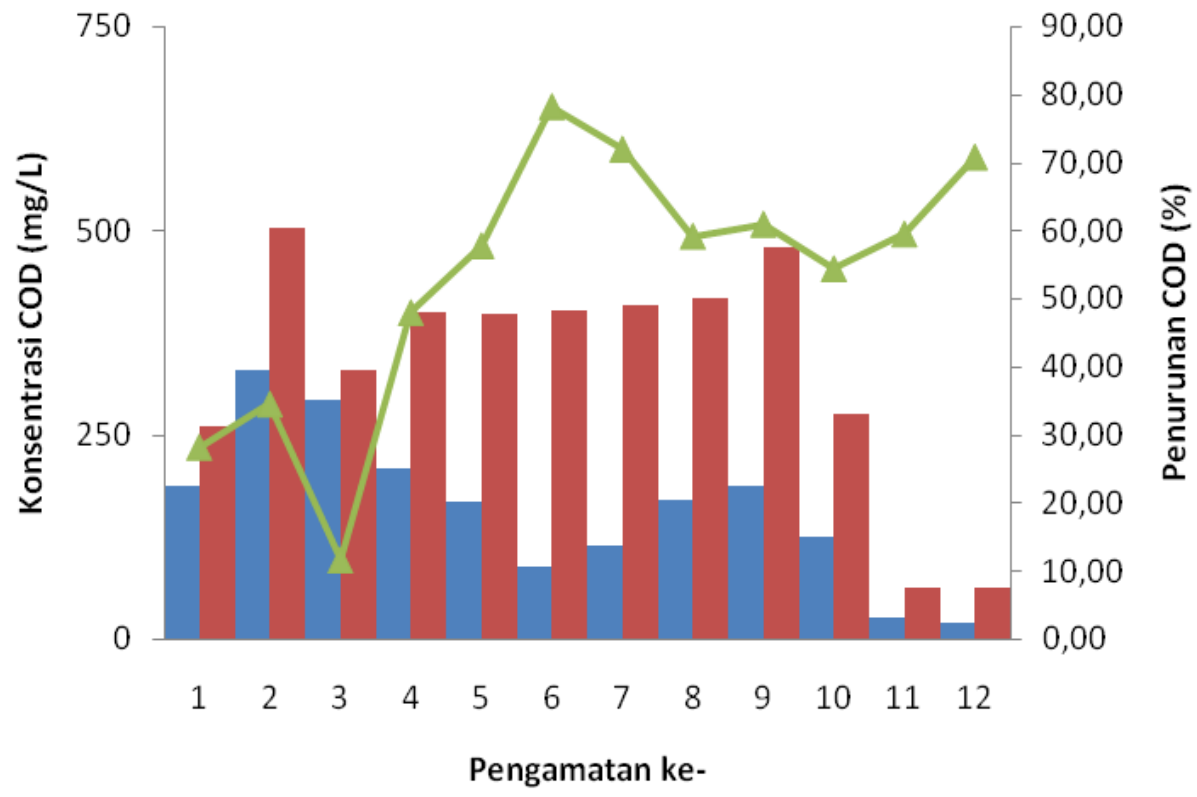

COD Outlet COD inlet $\quad-$ Penurunan COD

Gambar 5. Grafik Penurunan COD di Unit Wetland

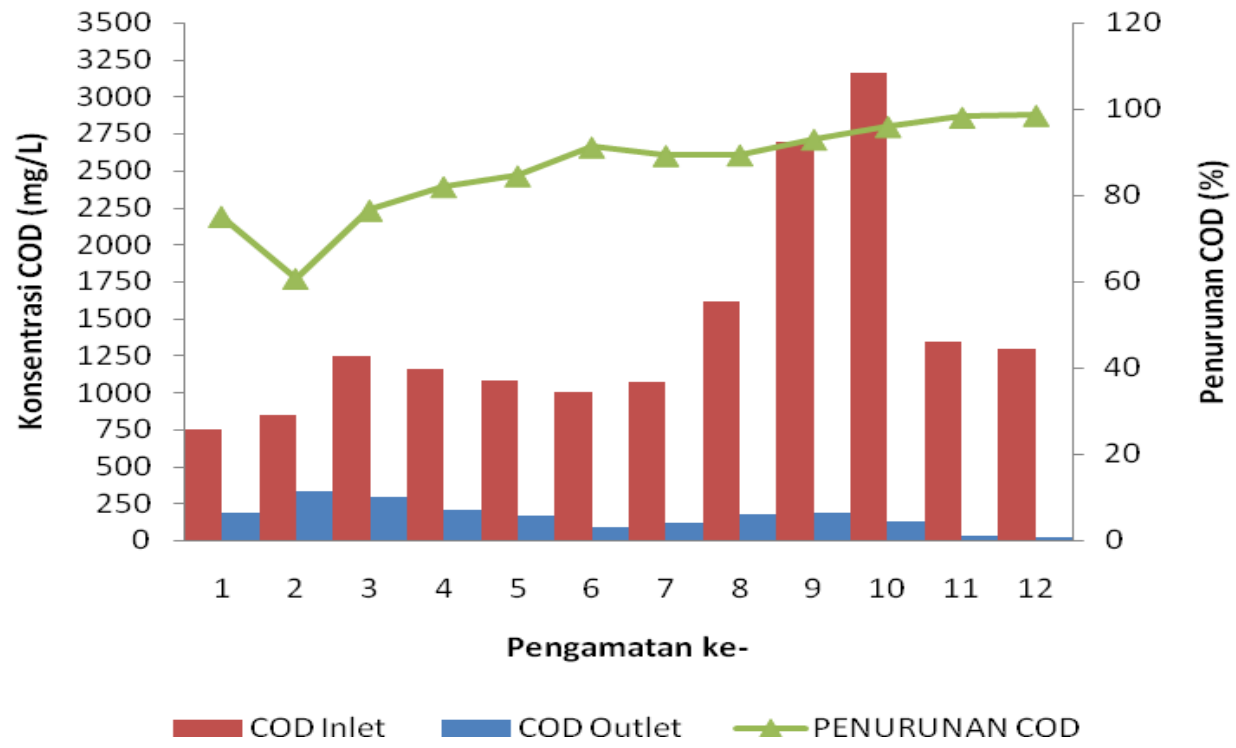

Gambar 6. Grafik Penurunan COD di IPAL hibrid UASB-Wetland 
Tabel 1. Hasil Analisis Air Limbah Terolah

\begin{tabular}{|c|c|c|c|c|c|c|}
\hline \multirow{2}{*}{ No. } & \multirow{2}{*}{ PARAMETER } & \multirow{2}{*}{ Satuan } & \multicolumn{3}{|c|}{ HASIL ANALISIS } & \multirow{2}{*}{$\begin{array}{c}\text { Permen LH No.5 } \\
\text { tahun } 2014 \\
\text { Baku Mutu Air } \\
\text { Limbah Golongan I }\end{array}$} \\
\hline & & & 1 & 2 & 3 & \\
\hline & I. FISIKA & & & & & \\
\hline 1. & Temperatur & ${ }^{\circ} \mathrm{C}$ & 30,0 & 28 & 28 & 38 \\
\hline 2. & TDS & $\mathrm{mg} / \mathrm{L}$ & 394 & 442 & 384 & 2000 \\
\hline \multirow[t]{2}{*}{3.} & TSS & $\mathrm{mg} / \mathrm{L}$ & 11 & 14 & 3 & 200 \\
\hline & II. KIMIA & & & & & \\
\hline 1. & $\mathrm{pH}$ & - & 7,4 & 7,4 & 7,8 & $6,0-9,0$ \\
\hline 2. & Besi terlarut ( $\mathrm{Fe}$ ) & $\mathrm{mg} / \mathrm{L}$ & $<0,010$ & 0,044 & 0,160 & 5 \\
\hline 3. & Mangan terlarut ( $\mathrm{Mn}$ ) & $\mathrm{mg} / \mathrm{L}$ & $<0,010$ & $<0,010$ & $<0,010$ & 2 \\
\hline 4. & Barium (Ba) & $\mathrm{mg} / \mathrm{L}$ & $<0,030$ & $<0,030$ & $<0,030$ & 2 \\
\hline 5. & Tembaga ( Cu ) & $\mathrm{mg} / \mathrm{L}$ & $<0,005$ & $<0,005$ & $<0,005$ & 2 \\
\hline 6. & Seng $(\mathrm{Zn})$ & $\mathrm{mg} / \mathrm{L}$ & $<0,010$ & $<0,010$ & $<0,010$ & 5 \\
\hline 7. & Khrom heksavalen $\left(\mathrm{Cr}^{6+}\right)$ & $\mathrm{mg} / \mathrm{L}$ & $<0,001$ & 0,005 & 0,001 & 0.1 \\
\hline 8. & Khrom total ( $\mathrm{Cr}$ ) & $\mathrm{mg} / \mathrm{L}$ & $<0,010$ & $<0,010$ & $<0,010$ & 0.5 \\
\hline 9. & Kadmium ( Cd ) & $\mathrm{mg} / \mathrm{L}$ & $<0,005$ & $<0,005$ & $<0,005$ & 0.05 \\
\hline 10. & Air raksa $(\mathrm{Hg})$ & $\mathrm{mg} / \mathrm{L}$ & $<0,001$ & $<0,001$ & $<0,001$ & 0,005 \\
\hline 11. & Timbal ( Pb) & $\mathrm{mg} / \mathrm{L}$ & $<0,030$ & $<0,030$ & $<0,030$ & 0.1 \\
\hline 12. & $\operatorname{Arsen}($ As ) & $\mathrm{mg} / \mathrm{L}$ & $<0,003$ & $<0,003$ & $<0,003$ & 0.1 \\
\hline 13. & Selenium (Se) & $\mathrm{mg} / \mathrm{L}$ & $<0,002$ & $<0,002$ & $<0,002$ & 0,05 \\
\hline 14. & Nikel ( Ni ) & $\mathrm{mg} / \mathrm{L}$ & $<0,050$ & $<0,050$ & $<0,050$ & 0.2 \\
\hline 15. & Sianida ( CN- ) & $\mathrm{mg} / \mathrm{L}$ & 0,003 & 0,005 & $<0,001$ & 0.05 \\
\hline 16. & Flourida ( F- ) & $\mathrm{mg} / \mathrm{L}$ & 0,236 & 0,175 & 0,297 & 2 \\
\hline 17. & Klorin bebas $(\mathrm{Cl} 2)$ & $\mathrm{mg} / \mathrm{L}$ & 0,13 & 0,10 & 0,05 & 1 \\
\hline 18. & Nitrat $\left(\mathrm{NO}_{3}-\mathrm{N}\right)$ & $\mathrm{mg} / \mathrm{L}$ & 8,57 & 7,02 & 1,55 & 20 \\
\hline 19. & Nitrit $\left(\mathrm{NO}_{2}-\mathrm{N}\right)$ & $\mathrm{mg} / \mathrm{L}$ & 7,274 & 6,602 & 0,298 & 1 \\
\hline 20. & $\mathrm{BOD}_{5}$ & $\mathrm{mg} / \mathrm{L}$ & 6,442 & 10,89 & 5,331 & 50 \\
\hline 21. & COD & $\mathrm{mg} / \mathrm{L}$ & 45,55 & 25,19 & 17,61 & 100 \\
\hline 22. & MBAS & $\mathrm{mg} / \mathrm{L}$ & $<0,010$ & 0,009 & 0,014 & 5 \\
\hline 23. & Fenol & $\mathrm{mg} / \mathrm{L}$ & $<0,001$ & $<0,001$ & 0,002 & 0.5 \\
\hline 24. & Minyak \& lemak & $\mathrm{mg} / \mathrm{L}$ & $<0,001$ & $<0,001$ & $<0,001$ & 10 \\
\hline
\end{tabular}

Tabel 2. Hasil analisis Air Limbah Terolah dibandingkan Kriteria Mutu Air untuk Budidaya Perikanan

\begin{tabular}{|c|c|c|c|c|}
\hline No. & Parameter & Satuan & $\begin{array}{c}\text { Hasil } \\
\text { Analisis }\end{array}$ & $\begin{array}{c}\text { Kriteria Mutu Air kelas III } \\
\text { (kegiatan budidaya } \\
\text { perikanan) } \\
\text { PP. No. } 82 \text { tahun } 2001 \\
\end{array}$ \\
\hline & I. FISIKA & & & \\
\hline 1. & Temperatur & ${ }^{\circ} \mathrm{C}$ & 28,3 & 38 \\
\hline 2. & Residu Terlarut & $\mathrm{mg} / \mathrm{L}$ & 250 & 1000 \\
\hline \multirow[t]{2}{*}{3.} & Residu Tersuspensi & $\mathrm{mg} / \mathrm{L}$ & 4 & 400 \\
\hline & II. KIMIA & & & \\
\hline 1. & $\mathrm{pH}$ & - & 7,5 & $6,0-9,0$ \\
\hline 2. & BOD & $\mathrm{mg} / \mathrm{L}$ & 6,75 & 6 \\
\hline 3. & COD & $\mathrm{mg} / \mathrm{L}$ & 13,76 & 50 \\
\hline 4. & DO & $\mathrm{mg} / \mathrm{L}$ & 3,97 & 3 \\
\hline 5. & Total Fosfat sebagai $\mathrm{P}$ & $\mathrm{mg} / \mathrm{L}$ & 0,229 & 1 \\
\hline 6. & $\mathrm{NO}_{3}$ sebagai $\mathrm{N}$ & $\mathrm{mg} / \mathrm{L}$ & 4,17 & 20 \\
\hline 7. & $\operatorname{Arsen}(\mathrm{As})$ & $\mathrm{mg} / \mathrm{L}$ & $<0,003$ & 1 \\
\hline 8. & Kobalt (Co) & & $<0,010$ & 0,2 \\
\hline 9. & Boron (B) & $\mathrm{mg} / \mathrm{L}$ & 0,516 & 1 \\
\hline 10 & Selenium $(\mathrm{Se})$ & $\mathrm{mg} / \mathrm{L}$ & $<0,002$ & 0,05 \\
\hline 11. & Kadmium (Cd) & $\mathrm{mg} / \mathrm{L}$ & $<0,005$ & 0,01 \\
\hline 12. & Khrom (Cr6+) & $\mathrm{mg} / \mathrm{L}$ & $<0,001$ & 0,05 \\
\hline 13. & Tembaga (Cu) & $\mathrm{mg} / \mathrm{L}$ & $<0,005$ & 0,2 \\
\hline 14. & Timbal (Pb) & $\mathrm{mg} / \mathrm{L}$ & $<0,030$ & 0,3 \\
\hline 15. & Air raksa $(\mathrm{Hg})$ & $\mathrm{mg} / \mathrm{L}$ & $<0,001$ & 0,002 \\
\hline 16. & Seng $(Z n)$ & $\mathrm{mg} / \mathrm{L}$ & $<0,010$ & 0,05 \\
\hline
\end{tabular}




\begin{tabular}{llllc}
\hline No. & \multicolumn{1}{c}{ Parameter } & Satuan & $\begin{array}{c}\text { Hasil } \\
\text { Analisis }\end{array}$ & $\begin{array}{c}\text { Kriteria Mutu Air kelas III } \\
\text { (kegiatan budidaya } \\
\text { perikanan) } \\
\text { PP. No. 82 tahun 2001 }\end{array}$ \\
\hline 17. & Sianida (CN) & $\mathrm{mg} / \mathrm{L}$ & $<0,001$ & 0,02 \\
\hline 18. & Fluorida (F) & $\mathrm{mg} / \mathrm{L}$ & 0,201 & 1,5 \\
\hline 19. & Nitrit sebagai N (NO2) & $\mathrm{mg} / \mathrm{L}$ & $<0,001$ & 0,06 \\
\hline 20. & Khlorin bebas & $\mathrm{mg} / \mathrm{L}$ & 0,03 & 0,03 \\
\hline 21. & Belerang sebagai H2S & $\mathrm{mg} / \mathrm{L}$ & 0,009 & 0,002 \\
\hline 22. & Minyak dan lemak & $\mathrm{mg} / \mathrm{L}$ & $<0,001$ & 1 \\
\hline 23. & Deterjen sebagai MBAS & $\mathrm{mg} / \mathrm{L}$ & 0,022 & 0,2 \\
\hline 24. & Senyawa phenol sebagai phenol & $\mathrm{mg} / \mathrm{L}$ & 0,001 & 0,001 \\
\hline
\end{tabular}

\section{KESIMPULAN}

Hasil uji coba penerapan IPAL dengan anaerob UASB menujukkan bahwa penurunan COD rata-rata $72,3 \%$ dengan penurunan tertinggi mencapai $95,42 \%$ dan penurunan COD pada proses wetland rata-rata $52,9 \%$ dengan penurunan tertinggi mencapai $78,22 \%$. Secara keseluruhan proses IPAL hibrid UASB-Wetland mampu menurunkan nilai COD rata-rata $86,25 \%$ dengan penurunan tertinggi mencapai $98,58 \%$. Air limbah terolah sudah memenuhi baku mutu yang disyaratkan dan dapat dimanfaatkan kembali (reuse) sebagai sumber air untuk budidaya perikanan darat. Air limbah terolah telah dimanfaatkan kembali (reuse) untuk budidaya perikanan yaitu budidaya ikan dimana ikan hasil budidaya tersebut digunakan sebagai bahan baku IKM itu sendiri.

\section{PERSANTUNAN}

Penulis menyampaikan terima kasih kepada Balai Besar Teknologi Pencegahan Pencemaran Industri atas dukungan pembiayaan penelitian ini melalui Program DIPA 2016. Penghargaan yang tinggi penulis sampaikan kepada Misbachul Moenir, Sartamtomo atas bantuan telaah dan diskusi selama penulisan naskah. Ucapan terima kasih juga penulis sampaikan kepada Laboratorium Pengujian BBTPPI dan Saifuddin sebagai analis

\section{DAFTAR PUSTAKA}

1. Chowdhury, P., Viraraghavan, T., \& Srinivasan, A. (2010). Biological Treatment Processes For Fish Processing Wastewater - A Review. Bioresource Technology, 101(2), 439-449. Https://Doi.Org/10.1016/ J.Biortech.2009.08.065

2. Setiyono, \& Yudo, S. (2010). Prototipe Instalasi Pengolahan Air Limbah Industri Pengolahan Ikan Di Kecamatan. J. Tek. Ling, 11(1), 7-26.

3. Alphenaar, P. A., Visser, A., \& Lettinga, G. (1993). the Effect of Liquid Upward
Velocity a N D Hydraulic Retention Time on Granulation in Uasb Reactors Treating Wastewater With a High Sulphate Content, 43, 249-258. https://doi.org/10.1016/09608524(93)90038-D

4. Bhunia, P., \& Ghangrekar, M. M. (2008). Analysis, evaluation, and optimization of kinetic parameters for performance appraisal and design of UASB reactors. Bioresource Technology, 99(7), 21322140.

https://doi.org/10.1016/j.biortech.2007.05.0 53

5. Moertinah, S., \& Sartamtomo. (2012). Pengolahan air limbahilndustri kertas secara Anaerobik UASB skala laboratorium pada berbagai suhu. Jurnal Riset Teknologi Pencegahan Pencemaran Industri Vol.2 No.1

6. Moenir, M., Sartamtomo, S., \& Moertinah, S. (2014). Pengolahan air limbah industri teh botol dengan teknologi biologis anaerobik uasb-wetland. Jurnal Riset Teknologi Pencegahan Pencemaran Industri, 5(2), 59-66. JOUR.

7. Geovana, P. G., Dinara, G. A., Marcos, F. J., Alexandre, L. N., Camila, F. de P., Leonardo, D. B. da S., \& Antônio, C. F. de M. (2016). Removal of nitrogen and phosphorus from cattle farming wastewater using constructed wetland system. African Journal of Agricultural Research, 11(44), 4542-4550.

https://doi.org/10.5897/AJAR2016.11425

8. Marlena, B., Yuliasni, R., Budiarto, A., Arum, S., Moenir, M., \& Syahroni, C. (2018). Jurnal Riset Teknologi Pencegahan Pencemaran Industri Removal of ammonia on catfish processing wastewater using horizontal sub-surface flow constructed wetland ( HSSFCW ), 9(1), 15-21.

9. lamchaturapatr, J., Yi, S. W., \& Rhee, J. S. (2007). Nutrient removals by 21 aquatic 
plants for vertical free surface-flow (VFS) constructed wetland. Ecological Engineering, 29(3),287-293. https://doi.org/10.1016/j.ecoleng.2006.09.0 10

10. Vymazal, J. (2014). Constructed wetlands for treatment of industrial wastewaters: A review. Ecological Engineering, 73, 724751.

https://doi.org/10.1016/j.ecoleng.2014.09.0 34

11. Marlena, B., Moenir, M., \& Yuliasni, R. (2017). Rancang bangun instalasi pengolahan air limbah industri pengolahan ikan dengan integrasi anaerobik uasb wetland wastewater treatment plant design of fish processing industry by integration of uasb-wetland Proceeding Seminar Nasional teknologi Industri Hijau II, 2017

12. Fedorak, P. M., \& Hrudey, S. E. (1986). Nutrient requirements for the methanogenic degradation of phenol and p-cresol in anaerobic draw and feed cultures. Water Research, 20(7), 929-933. https://doi.org/10.1016/00431354(86)90183-1

13. Wolmarans, B., \& De Villiers, G. H. (2002). Start-up of a UASB effluent treatment plant on distillery wastewater. Water SA, 28(1), 63-68. https://doi.org/10.4314/wsa.v28i1.4869

14. Ghangrekar, M. M., Ranganathan, K. ., Asolekar, S. ., \& Joshi, S. . (1996). Experience with UASB Reactor Start up under different operating condition. Wat. Sci. Tech, 34, 421-428.

15. Meer, R. R. Van Der, \& Vletter, R. De. (2016). Anaerobic treatment of wastewater: the gas-l? quid sludge separator, 54(11), 1482-1492. 
